\title{
Effect of Leadership and Motivation on the Employee Performance Through Work Environment as Intervening Variable (Case Study at PT ATS)
}

\author{
Bambang Dwi Laksono \\ Magister Management Student, Mercubuana University, Jakarta, Indonesia \\ M. Ali Iqbal \\ Senior Lecturer in Magister Management Program, Mercubuana University, Jakarta, Indonesia
}

\begin{abstract}
The aim of this study is to analyse the effect of leadership and motivation, using work environment as intervening variable, on the employee performance in the context of PT ATS. In this study, a structured questionnaire was developed by using Likert scale and applied on 131 respondents, whom their various jobs are directly relating to the operations within observation period of 2019. Leadership and motivation act as independent variables, work environment as intervening and employee performance as dependent one. The method used for the research is quantitave, applying survey and path analysis technique. For data analysis purpose, SPSS is used for descriptive statistic and PLS applied for developing structural and measurement models. The outcome of this study shows that leadership has no significant effect on employee performance, both directly or indirectly, through work environment. Meanwhile, motivation has significant direct and indirect (through work environment) effect to the performance of employees. Both leadership and motivation, have significant direct effect on the work environment. Work environment also has direct effect significantly on the employee performance significantly. Work environment also performs as full mediator within the effect of leadership to the employee performance. In the meantime, work environment contributes as partial mediator within the effect of motivation to the employee performance.
\end{abstract}

Keywords: Leadership, Motivation, Work Environment, Employee Performance

DOI: $10.7176 / \mathrm{EJBM} / 12-3-09$

Publication date: January $31^{\text {st }} 2020$

\section{Introduction}

1.1. Background

Human resource plays salient role in the company's operations. Without this reliable resource, the usage of other sources will not be effective and efficient. Sinambela (2018) opines that human in each organization, both business and public, is the main resource, beside others, such as money, material, machine, method and market. Meanwhile, Wibowo (2017) views that for organisations, including the companies, increase of competitiveness durability, are a must. However, the competitiveness of an organization will only be improved if they may adopt themselves with increase of internal performance and keep observing the external changes.

In the implementation of sustainable palm oil, human resource contributes significantly. Human establishes identification, planning, implementation, evaluation, and also drives other resources to ensure this system is well implemented. Human resource is also part of sectors, which included into the principles and criteria of sustainability system. One of indicators in the Indonesian Sustainable Palm Oil (ISPO) is that the availability of human resources system. This includes remuneration, incentive, carrier path, performance evaluation, rights and obligations of workers, implementation of occupational safety and health, and increase of employee competence based upon the existing regulations.

ATS is a palm oil company, established in 1991, with status of domestic investment (PMDN). Concessions of ATS located in Tapung Hulu, Kampar District, and Kepenuhan Hulu, Rokan Hulu district, both in Riau Province, Indonesia. With regard to the production, fresh fruit bunches they produced relatively decreased up to $14.6 \%$ in 2018 from 80,471 tonnes in the previous two years. The crude palm oil (CPO) productions experienced the same trend, where in 2018 the production declined $11 \%$ from 15,414,05 tonnes in erlier two years ago. 
Table 1. PT ATS Production Plan and Realization

\begin{tabular}{|r|c|c|c|c|}
\hline \multirow{2}{*}{ Tahun } & \multicolumn{2}{|c|}{ Fresh Fruit Bunches } & \multicolumn{2}{c|}{ Crude Palm Oil } \\
\cline { 2 - 5 } & $\begin{array}{c}\text { Plan } \\
\text { (ton) }\end{array}$ & Realization (ton) & $\begin{array}{c}\text { Plan } \\
\text { (ton) }\end{array}$ & Realization (ton) \\
\hline 2016 & $99,144.68$ & $80,471.00$ & $20,820.38$ & $15,414.05$ \\
\hline 2017 & $91,199.50$ & $74,539.00$ & $18,695.90$ & $14,249.60$ \\
\hline 2018 & $67,610.81$ & $68,694.00$ & $13,691.19$ & $13,133.08$ \\
\hline
\end{tabular}

Sources: PT ATS 2019

Therefore, based on the above phenomena gap, it is necessary to investigate the factors influencing the employees performance, thus, we perform a case study of an Indonesian private company.

\subsection{Objective and Questions Formulated in the Study}

The aim of this study is to develop a model for analyzing the effect of leadership, motivation and work environment on the performance of ATS's employees. The sentences to be questioned from this study are as below:

1) the direct effect of leadership on the employee performance

2) the direct effect of motivation on the employee performance

3) the direct effect of leadership on the work environment

4) the direct effect of motivation on the work environment

5) the direct effect of work environment on the employee performance

6) the indirect effect of leadership on the employee performance through work environment as intervening variable

7) the indirect effect of motivation on the employee performance through work environment as intervening variable.

\section{Theoritical Framework and Hypothesis}

\subsection{Leadership}

According to Amirulllah (2015), leadership is the capability, related to behaviour and expertise, to influence others to achieve organisation's objectives. Leadership, in theory, is segmented into 3, i.e. character, charisma, and attitude. The character relates to any properties, which attach or should attach, to a leader, such as intelegence (capability to adopt and decide, knowledge and talk), personality (individualism, creativity, readiness, integrity, emotional balance), physical character and cooperation (sociability, tactic and diplomatic). Charisma stresses on the capability of a leader to influence his followers based on his supernatural or particular power. And attitude theory focuses on how the leader behaves to determine effectiveness.

Fahmi, Irham (2016) defined that a leader has a great effect on supporting increase of performance of the employees. In this globalisation era, the leadership needed should have high value of competence, and this value can only be achieved if that leader has adequate experience and knowledge. Having this kind of competence, the leader may improve quality of his sub-ordinates' performance. Zulkarnaen, AA and Tajuddin Pogo (2019) in his research found that leadership has positive and significant effect on the employee performance. This is in line with the other research where Irmayana, $\mathrm{N}$ et.al (2018) found that leadership has an effect on the employee performance. Riyanto A, et.al (2018) concluded in their research that leadershir can enhance employee performance. The opposite occurs in Habba, D et.al (2017) research, they stated that that leadership has no effect on performance. Danthi Ni Made Ari (2017) in her research found that leadership has a significant effect on work performance.

\subsection{Motivasi}

Mangkunegara (2017) defined motivation as a condition, which may drive an employee to support achieving organisation's goals. The employee will have maximum performance if they are highly motivated. Wibowo (2017) also opined that motivation is the psychological process of arising and driving behaviour to achieve the goal, or so called goal directed behaviour.

Asociated with theory of motivation, Marsono (2016) explained that Abraham Maslow developed Hierarchy of Needs Theory where human has five stages of hierarchy of needs, i.e. physiological needs (the foundation level of need for human to survive); safety needs; social needs; esteem needs; and self-cctualization needs (to utilise capability, skill, potency, expressing ideas and critic).

In their study, Ali, Amjad, et al (2016) concluded that partially, motivation has positive and significant effect on the performance of employees. This is in line with the other research conducted by Restuwati, DE and Masydzulhak (2019). Jeffrey, I. and Andtes, R.V. (2017) regarding the Effect of Leadership, Work Motivation and Work Environment toward Employee Performance. They stated that motivation partially has positive and significant effect on the employee performance. 


\subsection{Work Environment}

Al-Omari, Khaled. and Haneen Okasheh (2017) viewed that work environment may be anything surrounding the workers, which affect them while doing their work.

Sedarmayanti (2011) opined that in general, work environment is categorised into 2, i.e. physical and nonphysical environment. The physical environment is all physical conditions around work place, which may affect employees, directly and indirectly as well. Non-physical work environment is all conditions with regard to the work relation, vertically between superior and sub-ordinate or horizontally among sub-ordinates. This nonphysical work environment is as salient as the physical one. Working spirit of the employees is affected with non physical work environment, such as relation among employees or with the superior. If the relation is condusive then this will make employees comfortable, so that working spirit will be higher, and in turn, the performance, will be improved as well.

In their study, Puspitasari, DTD and Ahmad Badawy Saluy (2019) conclude that partially, work environment affects positively and significantly on the employee performance. Jeffrey, Ignatius and Andtes, Reisza Vallewey (2017) also provide similar conclusion, where the effect of work environment on the performance of employees partially is positive and significant. Work environment has positive and significant direct effect on the employee performance. This result is in line with the other study commenced by Samson, GN and Waiganjo M. (2015) .i.e. Effect of Workplace Environment on the Performance of Commecial Banks' Employees in Nakuru Town. This study also shows that physical and non physical work environment has effect significantly on the employee performance

\subsection{Performance}

Fahmi, Irham (2016) defined performance as the output of an organisation, profit oriented or non profit oriented resulted within a period of time. Mangkunegara (2017) categorised indicators of employee performance into 3 types, i.e. work quality (accuracy, carefulness, skill, and cleanliness); work quantity (output); and reliability (instruction, initiative, diligence, attitude to employees and teamwork).

Factors affecting performance, according to Inaray, et. al (2016) are leadership and motivation. Meanwhile, Elisiana, et. al (2016) concluded that significantly, employee performance is affected by leadership, motivation and work environment.

\subsection{Research Model and Hypothesis}

The Research model of this study is shown on Figure 1.1.

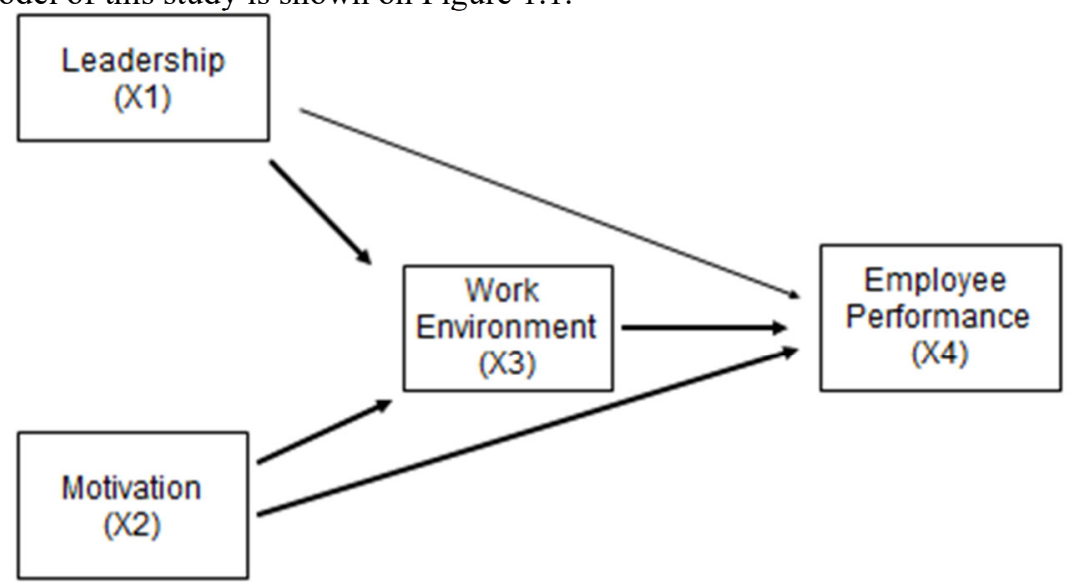

Figure 1.1. Research Model

Hypothesis

Based on the literature review, the results of the previous research and the model above, the hypothesis are as follows:

H1: Leadership affects directly on employee performance

$\mathrm{H} 2$ : Motivation affects directly on employee performance

H3: Leadership affects directly on work environment

H4: Motivation affects directly on work environment

H5: Work environment affects directly on employee performance

H6: Leadership affects indirectly on employee performance through work environment

H7: Motivation affects directly on employee performance through work environment. 


\section{Research Method}

The method used for the research is quantitave, applying survey and path analysis technique. Path analysis, according to Marsono (2016) is a mean or technique, which may assist researcher to elaborate the correlational causal quantitative data. There are 3 types of variables in this study, i.e. independent, dependent and intervening variables. In this study researchers distributed questionnaires to 131 employess whom their work relate to the production process of ATS estate. This estate is located in Tapung Hulu, Kampar District, Riau Province (Petapahan estate)

\section{Research Result and Discussion}

\subsection{Outer/Measurement Model}

According to Ghozali, Imam (2015), rule of thumb for Convergent Validity test is the value of Loading Factor $>$ 0.6 (for explanatory research), and AVE $>0.50$. The test shows that all dimensions, i.e. leadership ( 6 dimensions), motivation (5), work environment (2) and employee performance (5) have loading factor (original sampel) $>0.6$. Meanwhile, AVE values for leadership, motivation, work environment, and employee performance are $>0.5$. Therefore, we may conclude that the structural model is valid.

Table 4.1. Loading Factor Value

\begin{tabular}{cccccc}
\hline & $\begin{array}{c}\text { Original } \\
\text { Sample } \\
(\mathrm{O})\end{array}$ & $\begin{array}{c}\text { Sample } \\
\text { Mean } \\
(\mathrm{M})\end{array}$ & $\begin{array}{c}\text { Standard } \\
\text { Deviation } \\
(\text { STDEV })\end{array}$ & $\begin{array}{c}\text { T Statistics } \\
(|\mathrm{O} / \mathrm{STDEV}|)\end{array}$ & $\begin{array}{c}\text { P } \\
\text { Values }\end{array}$ \\
\hline K1 < Leadership (K) & 0,715 & 0,706 & 0,066 & 10,861 & 0,000 \\
K2 < Leadership (K) & 0,798 & 0,797 & 0,038 & 21,158 & 0,000 \\
K3 <-Leadership_(K) & 0,736 & 0,731 & 0,072 & 10,197 & 0,000 \\
K4 <- Leadership_(K) & 0,831 & 0,830 & 0,033 & 24,975 & 0,000 \\
K5 <- Leadership_(K) & 0,777 & 0,776 & 0,042 & 18,624 & 0,000 \\
K6 <- Leadership_(K) & 0,788 & 0,784 & 0,049 & 15,954 & 0,000 \\
KK1 <- Employee Performance_(KK) & 0,828 & 0,828 & 0,042 & 19,760 & 0,000 \\
KK2 <- Employee Performance_(KK) & 0,834 & 0,832 & 0,034 & 24,297 & 0,000 \\
KK3 <- Employee Performance_(KK) & 0,730 & 0,708 & 0,110 & 6,666 & 0,000 \\
L1 <- Work Environment_(L) & 0,887 & 0,884 & 0,029 & 30,848 & 0,000 \\
L2 <- Work Environment_(L) & 0,913 & 0,912 & 0,018 & 50,388 & 0,000 \\
M1 <- Motivation_(M) & 0,726 & 0,724 & 0,046 & 15,623 & 0,000 \\
M2 <- Motivation_(M) & 0,812 & 0,803 & 0,042 & 19,311 & 0,000 \\
M3 <- Motivation_(M) & 0,743 & 0,737 & 0,060 & 12,412 & 0,000 \\
M4 <- Motivation_(M) & 0,827 & 0,826 & 0,036 & 22,693 & 0,000 \\
M5 <- Motivation_(M) & 0,741 & 0,735 & 0,062 & 11,975 & 0,000 \\
\hline
\end{tabular}

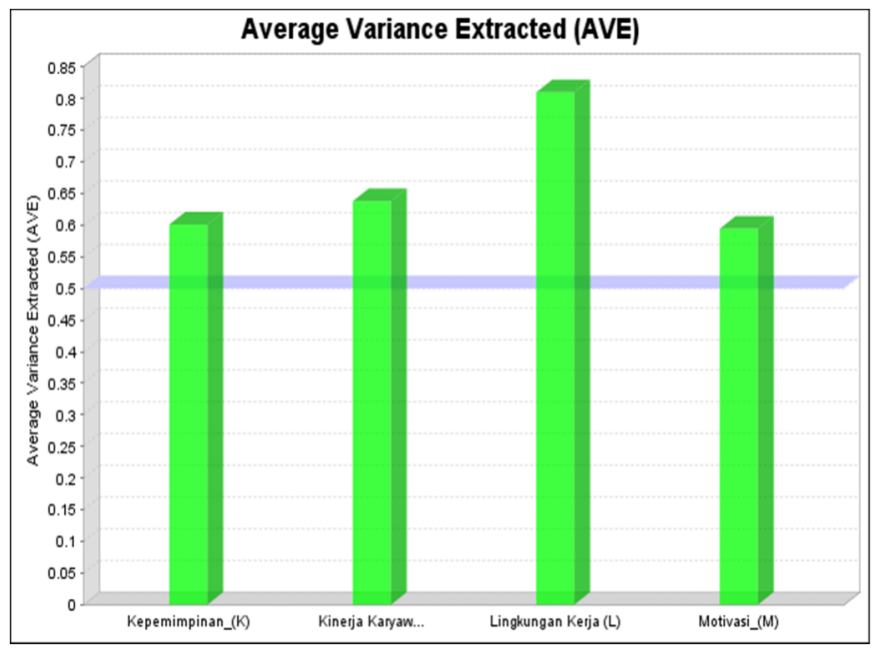

Figure 4.1. Average Variance Extraxted (AVE)

Discriminant validity is tested using cross loading parameter. If the value of cross loading of each indicator on their construct is higher than the other construct, then this measurement model is considered valid (Ghozali, Imam. (2015). The result of the test showed that the value of cross loading of each indicator is higher that other construct, therefore we may conclude that this measurement modek is valid. 
Table 4.2. Cross Loading

\begin{tabular}{ccccc}
\hline Dimension & Leadership_(K) & Employee Performance_(KK) & Work Environment_(L) & Motivation_(M) \\
\hline K1 & 0,715 & 0,266 & 0,339 & 0,477 \\
K2 & 0,798 & 0,345 & 0,475 & 0,483 \\
K3 & 0,736 & 0,435 & 0,359 & 0,445 \\
K4 & 0,831 & 0,400 & 0,427 & 0,537 \\
K5 & 0,777 & 0,328 & 0,420 & 0,545 \\
K6 & 0,788 & 0,292 & 0,414 & 0,523 \\
KK1 & 0,357 & 0,828 & 0,546 & 0,473 \\
KK2 & 0,373 & 0,834 & 0,581 & 0,579 \\
KK3 & 0,351 & 0,373 & 0,344 \\
L1 & 0,435 & 0,730 & 0,887 & 0,537 \\
L2 & 0,508 & 0,533 & 0,580 \\
M1 & 0,422 & 0,617 & 0,913 & 0,726 \\
M2 & 0,477 & 0,382 & 0,517 & 0,812 \\
M3 & 0,537 & 0,349 & 0,376 & 0,743 \\
M4 & 0,508 & 0,573 & 0,515 & 0,827 \\
M5 & 0,538 & 0,524 & 0,489 & 0,741 \\
\hline
\end{tabular}

The reliability test of the construct to the reflective indicator, according to Ghozali, Imam. (2015), can be performed by two ways, i.e. Cronbach's Alpha and Composite Reliability. The test resulted that the values of both Cronbach's Alpha andn Composite Reliability of each contruct is higher than 0.7 , therefore this measurement model is reliable.

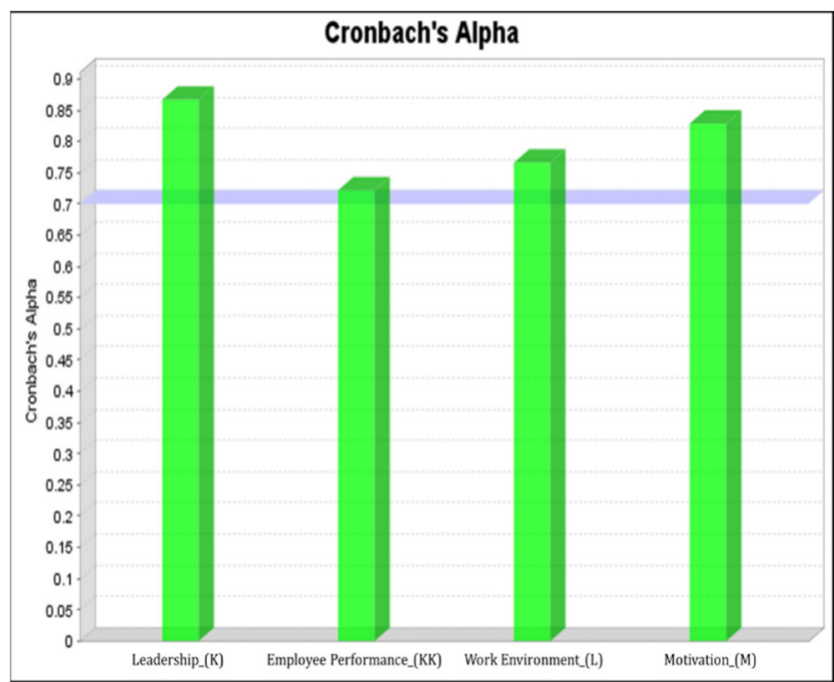

Figure 4.2. Cronbach's Alpha

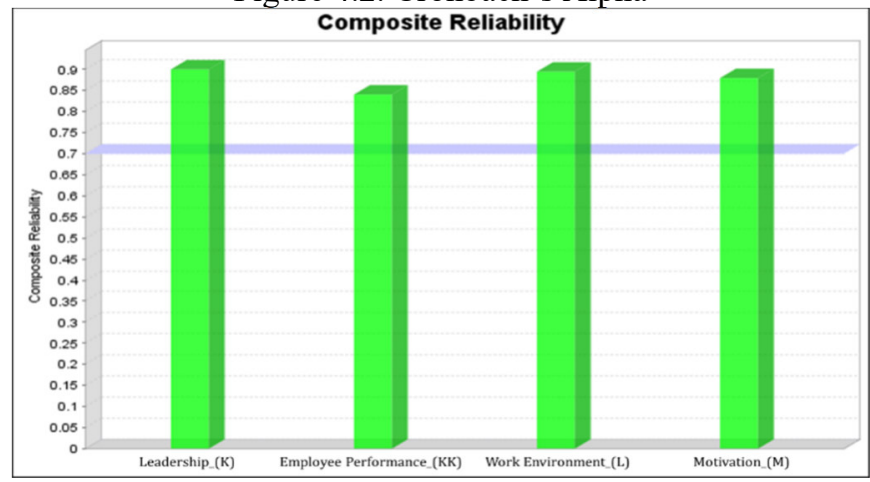

Figure 4.3. Composite Reliability

\subsection{Structural / Inner Model}

Related to the test for determinant coefficient $\left(\mathrm{R}^{2}\right)$, according to Chin in Ghozali, Imam (2015), if the value of $\mathrm{R}^{2}$ is 0.67 ; 0.33 ; and 0.19 show, in sequence, the model is strong, moderate and weak. Table 4.2 . shows that $\mathrm{R}^{2}$ for work environment is 0.413 or moderate. Therefore, we conclude that the contribution of leadership and motivation to influence work environment is $41.3 \%$. And the other remaining portion is contributed by variables, which are not part of this study. $\mathrm{R}^{2}$ for employee performance is 0.477 or moderate. Therefore, we conclude that the contribution of leadership, motivation and work environment to influence employee performance is $47.7 \%$. And 
the other remaining portion is contributed by variables, which are not part of this study.

Table 4.2. Determinat Coeficient

\begin{tabular}{ccc}
\hline Variable & R Square & R Square Adjusted \\
\hline Employee Performance (KK) & 0,477 & 0,465 \\
Work Environment (L) & 0,413 & 0,404 \\
\hline
\end{tabular}

The scores of $\mathrm{R}^{2}$ may also be shown in the structural model as below:

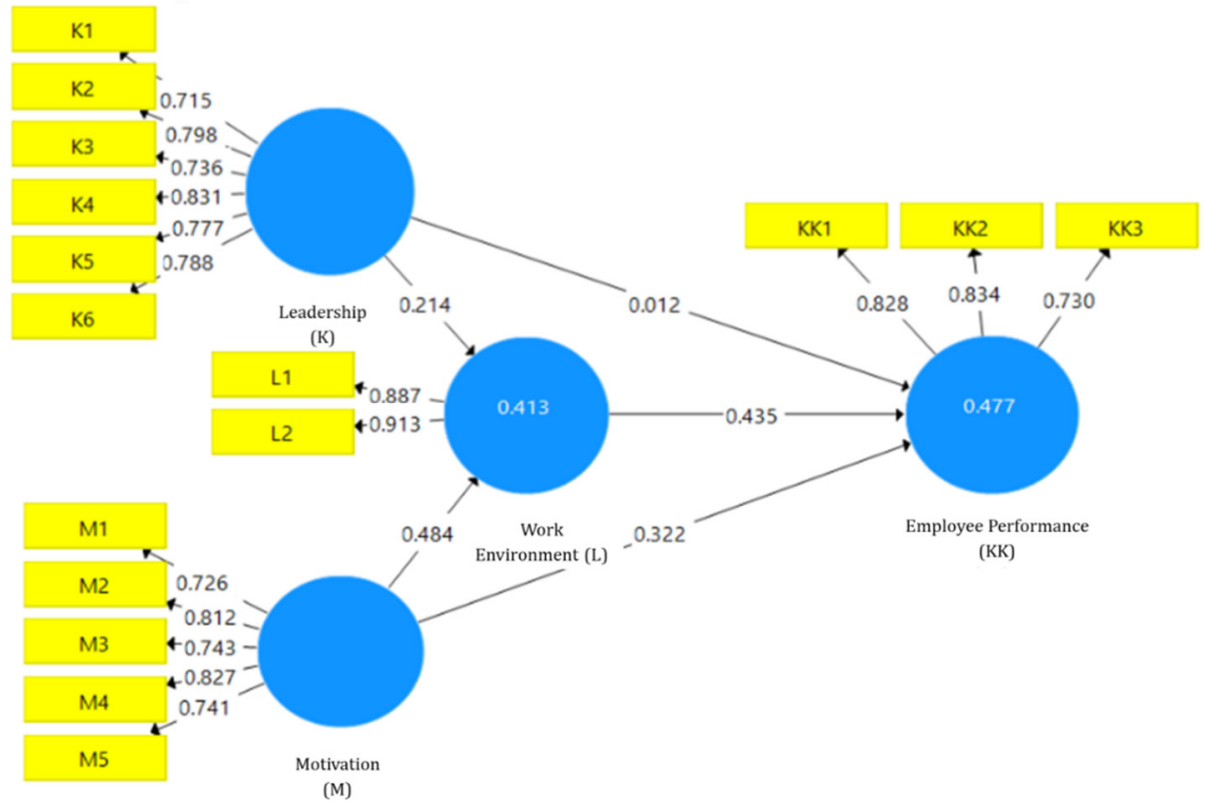

Figure 4.4. Loading Factor and Determinant Coefficient

The score for $\mathrm{Q}^{2}$ is 0.693 therefore the model has a strong predictive relevance $\left(\mathrm{Q}^{2}>0\right)$. Related to $\mathrm{f}^{2}$, the score for motivation to work environment is 0.232 (moderate), work environment to employee performance is 0.212 (moderate), leadership to work environment is 0.045 (weak), leadership to employee performance is 0.000 (weak), and motivation to employee performance is 0.093 (weak).

\subsection{Hypothesis Test}

The hypothesis test uses score of T-Statistics and P-Values as parameters. If T-Statistics $>\mathrm{T}$ Table (1.96 at significance level of 0.05 ) or P-Values $<0.05$, then hypothesis is accepted. The result of the test is shown in the tables below:

\begin{tabular}{lccccc}
\multicolumn{1}{c}{ Table 4.3. Direct Effect Test } \\
\hline Direct Effect & $\begin{array}{c}\text { Original } \\
\text { Sample } \\
(\mathrm{O})\end{array}$ & $\begin{array}{c}\text { Sample } \\
\text { Mean } \\
(\mathrm{M})\end{array}$ & $\begin{array}{c}\text { Standard } \\
\text { Deviation } \\
(\text { STDEV) }\end{array}$ & $\begin{array}{c}\text { T Statistics } \\
(|\mathrm{O} / \mathrm{STDEV}|)\end{array}$ & $\begin{array}{c}\mathrm{P} \\
\text { Values }\end{array}$ \\
\hline Leadership (K) -> Employee Performance (KK) & 0,012 & 0,010 & 0,101 & 0,123 & 0,902 \\
Leadership (K) -> Work Environment (L) & 0,214 & 0,227 & 0,092 & 2,324 & 0,021 \\
Work Environment (L) -> Employee Performance (KK) & 0,435 & 0,409 & 0,151 & 2,874 & 0,004 \\
Motivation (M) -> Employee Performance (KK) & 0,322 & 0,346 & 0,156 & 2,064 & 0,040 \\
Motivation (M) -> Work Environment (L) & 0,484 & 0,472 & 0,115 & 4,204 & 0,000 \\
\hline
\end{tabular}

The original sample of the effect of leadership variable on employee performance is positive (0.012). This indicates that there is a positif relation between leadership and employee performance. Then, $t$-statistic score is $0.123(<1.96)$ and $\mathrm{P}$ value achieves $0.902(>0.05)$. We may conclude, based on those values, that leadership variable has no significant effect on the employee performance.

The original sample of the effect of leadership variable on work environment is positive $(0.214)$. This indicates that there is a positif relation between leadership and work environment. Then, t-statistic score is 2.324 $(>1.96)$ and $\mathrm{P}$ value achieves $0.021(<0.05)$. We may conclude, based on those values, that leadership variable has a significant effect on the work environment.

The original sample of motivation variable towards employee performance is positive, i.e. 0.322 . This indicates that there is positive relation between motivation and employee performace. Then, $\mathrm{t}$-statistic score is 2.064 ( > 1.96), and the $\mathrm{P}$ value achieves $0.040(<0.05)$. Therefore, we may conclude that motivation variable has significant effect on the employee. The original sample of leadership variable towards work environment is positive 
( 0.214). This indicates that there is positif relation between leadership and work environment. Then, t-statistic shows $2.324(>1,96)$, and P value- achieves $0.021(<0.05)$. We may conclude that leadership has significant effect on the work environment.

The original sample of motivation variable towards work environment is positive ( 0.484$)$. This indicates that there is positif relation between motivation and work environment. Then, t-statistic shows $4.204(>1.96)$, and P value- achieves $0.000(<0.05)$. We may conclude that motivation has significant effect on the work environment.

The original sample of work environment variable towards work employee performance is positive ( 0.435$)$. This indicates that there is positif relation between work environment and employee performance is $2.874(>1.96)$, and $\mathrm{P}$ value achieves $0.004(<0.05)$. From the previous data, we may summarise that work environment has significant effect on the employees; performance.

Table 4.4. Indirect Effect Test

\begin{tabular}{lccccc}
\hline \multicolumn{1}{c}{ Indirect Effect } & $\begin{array}{c}\text { Original } \\
\text { Sample } \\
(\mathrm{O})\end{array}$ & $\begin{array}{c}\text { Sample } \\
\text { Mean } \\
(\mathrm{M})\end{array}$ & $\begin{array}{c}\text { Standard } \\
\text { Deviation } \\
\text { (STDEV) }\end{array}$ & $\begin{array}{c}\text { T Statistics } \\
(|\mathrm{O} / \mathrm{STDEV}|)\end{array}$ & $\begin{array}{c}\mathrm{P} \\
\text { Values }\end{array}$ \\
\hline $\begin{array}{l}\text { Leadership (K) -> Work Environment (L) }-> \\
\text { Employee Performance (KK) }\end{array}$ & 0,093 & 0,098 & 0,063 & 1,463 & 0,144 \\
\hline $\begin{array}{l}\text { Motivation (M) -> Work Environment (L) -> } \\
\text { Employee Performance (KK) }\end{array}$ & 0,210 & 0,183 & 0,062 & 3,365 & 0,001 \\
\hline
\end{tabular}

Tabel 4.4. shows that original sample of leadership variable towards employee performance via work environment has a positive score (0.093). This means that there is positive relation between leadership variable towards employee performance via work environment. Then, t-statistic is $1.463(<1.96)$, and P value achieves $0.144(>0.05)$. Therefore, we may conclude that leadership has no significant indirect effect on the employee performance (through work environment).

The original sample of motivation variable towards employee performance via work environment has a positive score $(0.210)$. This means that there is positive relation between motivation variable towards employee performance via work environment. Then, t-statistic is $3.365(>1.96)$, and $\mathrm{P}$ value achieves $0.001(<0.05)$. Therefore, we may conclude that motivation has significant indirect effect on the employee performance (through work environment).

\begin{tabular}{cccccc}
\multicolumn{7}{c}{ Table 4.5. Total Effect Test } \\
Total Effect & $\begin{array}{c}\text { Original } \\
\text { Sample } \\
(\mathrm{O})\end{array}$ & $\begin{array}{c}\text { Sample } \\
\text { Mean } \\
(\mathrm{M})\end{array}$ & $\begin{array}{c}\text { Standard } \\
\text { Deviation } \\
(\text { STDEV) }\end{array}$ & $\begin{array}{c}\text { T Statistics } \\
(|\mathrm{O} / \mathrm{STDEV}|)\end{array}$ & $\begin{array}{c}\mathrm{P} \\
\text { Values }\end{array}$ \\
\hline Leadership (K) -> Employee Performance (KK) & 0,105 & 0,108 & 0,110 & 0,956 & 0,340 \\
Motivation (M) -> Employee Performance (KK) & 0,532 & 0,530 & 0,131 & 4,057 & 0,000 \\
\hline
\end{tabular}

Original sample of direct effect of leadership on employee performance is lesser than original sample of indirect effect of leadership on employee performance $(0.012<0.093)$. Therefore, this indicates that direct effect of leadership on employee performance is lesser than indirect effect of leadership on employee performance. Then the ratio of direct effect to indirect effect of leadership on employee performance $(0.093 / 0.105)$ shows VAF score of $88 \%$. This indicates that work environment performs as full mediator.

Original sample of direct effect of motivation on employee performance is bigger that original sample of indirect effect of motivation, via work environment, on employee performance $(0.323>0.210)$. Therefore, this means that direct effect of motivation on employee performance is bigger than indirect effect of motivation on employee performance (via work environment). The ration between indirect effect to direct effect of motivation on employee performance $(0.210 / 0.532)$ shows $39 \%$ as VAF score. This indicates that work environment performes as partial mediator.

\section{Conclusion}

\subsection{Practical Implementation}

In improving the performance of employess, we recommend that the this palm oil company consider motivation and work environment characteristics because these two variables have a significant influence on employee performance. Therefore this palm oil company should analyze overtime these two variables such that these two variables can be adjusted. In improving work environment we also recommend that the this palm oil company consider leadership and motivation characteristics because these two variables have a significant influence on work environment.

\subsection{Theoritical Contributions}

Leadership has positive and significant effect directly on work performance. This research in line with the previous 
research by Danthi Ni Made Ari (2017) in her research found that leadership has a significant effect on work performance. Motivation has positive and significant effect, directly and indirectly (through work environment) on the employee performance. This result is in line with the previous study conducted by Jeffrey, I. and Andtes, R.V. (2017) regarding the Effect of Leadership, Work Motivation and Work Environment toward Employee Performance. They stated that motivation partially has positive and significant effect on the employee performance. Besides that, Restuwati, DE and Masydzulhak (2019), in their research named The Effect of Leadership, Motivation, and Work Culture on the Employee Performance PT XYZ, also concluded that motivation variable has positive and significant effect on the employee performance.

Work environment has positive and significant direct effect on the employee performance. This result is in line with the other study commenced by Samson, GN and Waiganjo M. (2015) .i.e. Effect of Workplace Environment on the Performance of Commecial Banks' Employees in Nakuru Town. This study also shows that physical and non physical work environment has effect significantly on the employee performance. Puspitasari, DTD and Ahmad Badawy Saluy (2019) conclude that partially, work environment affects positively and significantly on the employee performance

\subsection{Research Limitation}

This study exclude other variables, which may affect to the employee performance, such as remuneration, discipline, loyalty, and organization culture. Besides that, this study located only in one of palm oil companies, so that we are unable to generate the result for the whole palm oil industry. Due to measurement of this study, which only applied in certain period, the result of the study may not be set up for long-term period. A longer period of study is necessary to respond if the conclusion of this study is still applicable for long-term.

\subsection{Future Research Direction}

In the future, the scope of this study can be developed, not only within a single palm oil company, buy can be extended to some other similar companies. Long-term study is possibly conducted to have applicable conclusion for long-term period.

\section{REFERENCES}

Al-Omari, K., and Haneen O. (2017). "The Influence of Work Environment on Job Performance: A Case Study of Engineering Company in Jordan”. International Journal of Applied Engineering Research, Volume 12, No. 24, pp. 15544-15550.

Ali, Amjad.et.al. (2016). The Impact of Motivation on the Employee Performance and Job Satisfaction in IT Park (Software House) Sector of Peshawar, Pakistan. International Journal of Academic Research in Business and Social Sciences, Vol.6, No. 9, Pp. 297-310.

Amirullah. (2015). Kepemimpinan dan Kerja Sama Tim. Mitra Wacana Media. Jakarta.

Danthi NMA (2017). Pengaruh Gaya Kepemimpinan Terhadap Lingkungan Kerja, Motivasi Kerja dan Kinerja Pegawai Negeri Sipil Pada Badan Pemberdayaan Perempuan dan Perlindungan Anak Provinsi Bali. Jurnal Ekonomi dan Bisnis, Vol.4 No.1. Hal 83-94.

Elisiani, FY., Hari Susanta N., and Widiartanto. (2016). "The Effect of Leadership, Work Motivation and Work Environment of Employee Performance (Case Study of PT. Aneka Ilmu Semarang Section Printing)". Jurnal Administrasi Bisnis.

Fahmi, Irham. (2016). Pengantar Manajemen Sumber Daya Manusia. Mitra Wacana Media. Jakarta.

Ghozali, Imam and Hengky Latan. (2015). Partial Least Squares, Konsep, Teknik dan Aplikasi Menggunakan SmartPLS 3.0, Badan Penerbit Universitas Diponegoro, Semarang.

Habba D., Basri M, Muhammad JB, and Jamaluddin B. (2017). "The Effect of Leadership, Organisational Culture and Work Motivation on Job Satisfaction and Job Performance among Civil Servants in Maros District Technical Working Unit”. IRA-International Journal of Management \& Social Science, ISSN 2455-2267; Vol.07, Issue 01, pp.52-64.

Inaray, JC., Olivia SN and Victor PKL (2016). "Pengaruh Kepemimpinan dan Motivasi Kerja terhadap Kinerja Karyawan pada PT Amanah Finance di Manado”. Jurnal Berkala Ilmiah Efisiensi, Volume 16, No. 02.

Irmayana, N. Suryanto, and Chaeriah ES. (2018). "The Effect of Leadership and Work Environment to Employee Performance through Job Satisfaction at the Employment Training Center West Java Province". The International Journal of Business \& Management, Vol 6, Issue 2.

Jeffrey, I. and Reisza VD. (2017). "The Effect of Leadership, Work Motivation, and Work Environment toward Employees Performance". International Journal of Advanced Research, 5(8), 1450-1458.

Mangkunegara (2017). Manajemen Sumber Daya Manusia Perusahaan. Roada. Bandung.

Marsono. (2016). Metode Penelitian Kuantitatif, Langkah-Langlah Menyusun Skripsi, Tesis atau Disertasi Menggunakan Teknis Analisis Jalur (Path Analysis) Dilengkapi dengan Contoh Aplikasinya. In Media. Bogor.

Puspitasari, DTD and Ahmad Badawi Saluy. (2019). Pengaruh Lingkungan Kerja dan Disiplin Kerja terhadap 
Kinerja PNS pada Direktorat Aneka Kacang dan Umbi serta Direktorat Pasca Panen Direktorat Jenderal Tanaman Pangan. Indikator, Jurnal Ilmiah Manajemen dan Bisnis, Volume III, No. 2.

Restuwati, DE and Masydzulhak (2019). Pengaruh Kepemimpinan, Motivasi dan Budaya Kerja terhadap Kinerja Karyawan di PT XYZ. Indikator, Jurnal Ilmiah Manajemen dan Bisnis, Volume III, No.2.

Riyanto A., Susi H., and Yulia E. (2018). "Pengaruh Kepemimpinan dan Budaya Organisasi terhadap Kepuasan Kerja dan Kinerja Karyawan Bagian Produksi Kelapa Sawit pada PT Perkebunan Nusantara V Kebun Sei Galuh”. Jurnal Tepak Manajemen Bisnis, Vol X, No.2.

Samson, GN. and Waiganjo M. (2015). Effect of Workplace Environment on the Performance of Commercial Banks Employees in Nakuru Town. International Journal of Managerial Studies and Research (IJMSR), Volume 3, Issue 12, PP 76-89.

Sedamaryanti. (2011). Tata Kerja dan Produktifitas Kerja. Mandar Maju. Bandung.

Sinambela, LP. (2018). Manajemen Sumber Daya Manusia: Membangun Tim Kerja yang Solid untuk Meningkatkan Kinerja. Cetakan Ketiga. Bumi Aksara. Jakarta.

Wibowo. (2017). Manajemen Kinerja, Rajagrafindo Persada, Depok.

Zulkarnaen, AA and Tajuddin Pogo (2019). Pengaruh Kepemimpinan, Motivasi Kerja dan Disiplin Kerja terhadap Kinerja Karyawan PT Angkasa Pura Logistik. Indikator, Jurnal Ilmiah Manajemen dan Bisnis, Volume III, No. 1. 